\title{
Higher Qualification but Lower Jobs: Experiences of Women Teachers in Primary Schools of Uganda
}

\author{
Alice Merab Kagoda \\ Betty Akullu Ezati \\ College of Education and External Studies, \\ Makerere University, \\ Kampala-Uganda
}

\section{Doi:10.5901/jesr.2013.v3n5p125}

\begin{abstract}
Sixty female teachers and nine district education officers from three districts of Uganda participated in this study. The researchers were interested in the invisible female primary teachers who upgraded their qualifications with the hope of increasing their chances of promotion to higher positions within the education sector. The objectives of the study were; to identify reasons inspiring female teachers to upgrade and to assess to what extent female teachers expectations were met after upgrading their qualifications. Results shoe that the government policy is that a primary teacher is "grade three' with appropriate remuneration and benefits as policy. The affirmative policies inspired a large number of female grade three teachers to upgrade but their expectations were not met and are gravely frustrated at district and school levels. The following are recommendations; the Ministry of Education and Sports should revise the policy of remuneration so that qualifications of teachers are taken into consideration, the District Education officers should endeavor to implement the government policy of equal opportunities to promotion for both genders as recommended by the White Paper (1992)
\end{abstract}

\section{Introduction}

Women need to be in leadership positions in education systems worldwide to provide a gendered perspective on educational change and development, and to ensure social justice through gender equity at leadership and decision making level in Uganda (Sperandio and Kagoda (2009). School leadership is recognized as an essential element of school improvement and effectiveness. Countries committed to reform and development of their school system must now consider how best to prepare their school leaders to bring about needed changes. The development of a strong women's rights movement in Uganda, help from International human rights agencies, and a national government committed to international gender equity goals have increased opportunities for women to move into decision-making and leadership at all levels in the education system.

The $4^{\text {th }}$ World Conference on Women(1995) called for governments worldwide to "create a gender sensitive education system in order to ensure full and equal participation of women in educational administration and policy and decision making' (Beijing Declaration and Platform for Action (BPA) 1995, chapter 4, article 82). The BPA Mission Statement asserts that equality between women and men is not only a matter of human rights and a condition for social justice, but also a condition for 'people-centered sustainable development'(BPA, 1995, section 1). Uganda, in common with the majority other developing countries is, is still struggles to meet the goal of $30 \%$ representation of women in leadership roles in education that the Bejing platform considered 
critical for women to have an impact on decision-making (BPA 1995,section 181 and 182). In the late 1980s and early 1990s the Ugandan women's movement focused public attention on the state of primary and secondary education for girls, and the harassment of girls taking place in schools by boys and male teachers that contributed to a high drop-out rate for girls. This problem was noted by the Educational policy Review Commission's Report “Education for National Integration and Development (1990). The Commission recommended that "coeducational schools, either the head or deputy head should be a woman in order to give adequate attention to the special needs of girls (recommendation 163). This recommendation was accepted in the government White paper on Education (1992). This is used by the ministry of Education and Sports as a guideline when allocating vacant school administrative positions to qualified candidates. Private schools are expected to follow similar policies to the government aided schools. With this affirmative policies by the government of Uganda, many women were inspired to go for upgrading to take up such anticipated vacancies. This papers the status of women with high qualifications teaching in primary schools of Uganda (Sperandio and Kagoda 2008).

Upgrading ones' educational qualification should enable one to achieve professional, economic and social enhancement, but this has not always been true for both men and women. In many cases, men easily get and change jobs compared to women with the same qualification. There seems to be not only variations in what men and women do on completion of additional qualification but also the way society view men and women, in relation to what teachers who upgrade qualification do, outlets outside classroom teaching including becoming a head teacher, District Education Officer, Inspectors of schools or a Teacher Educator. All these posts however tend to be taken by men. This is evident in the fact that head ship in primary schools continues to be male dominated (Kagoda and Sperandio 2008). There are reports of employers considering the gender of their employees as an important factor during recruitment, placement and promotion of workers (Even in a profession which is female dominated, men tend to be in the upper echelons. Moreover women with higher qualification are not only a threat to their fellow male teachers but also the few females in management positions. This study analyzed women teachers' expectations for upgrading and whether those expectations were met.

Vravec \& Bacik (2012) identifies three models of discrimination; statistical discrimination in which an individual attributes and characteristics is based on that of the group from which he/she emerged, than according to their own individual attributes and characteristics. This means if the group is discriminated then the individual will also be affected. The second model is where expectations of employers determine the differences in the labour market for men and women. Where employers expect higher marginal product of men, the labour demand of men will be higher than labour demand of women. The third, discrimination based on monophony in which the work providers divide work into two categories according to elasticity of supply functions and will evaluate a group with smaller labour supply i.e. women by lower salary. Employers pay higher salaries to men with higher elasticity of labour supply. Labour supply curve is less elastic for women than men and therefore men achieve higher average salaries than equally productive women. Salary discrimination against women is usually not based on any tradition, whether oppression or underestimating of women, but from a purely economic reasons.

The labour supply for men is much more elastic than for women because women are less mobile geographically and professionally, they look for a job near their home. Vravec \& Bacik (2012) Women usually follow a man for his job opportunity and they are choosing between job offers in their region. In contrast, men can travel further to work; can work well in batch or at night. Men can change jobs more often than women, because they have more alternative opportunities in the labour market. 


\section{Context of the Study}

Uganda' education system is structured into three layers: primary level which takes seven years, secondary level six years (lower 4 years and higher 2 years) and tertiary 3 to 5 years. Since the 1990s, the Government of Uganda has focused on improving access and quality of education as evident in the Education Sector Investment Plan (ESIP) launched in 1998 and Education Sector Strategic plan (ESSP) (2004 - 2017). ESIP focus on (a) achieving equitable access to education at all levels; (b) Improving quality of education, particularly at the primary level; (c) Enhancing the management of education service delivery at all levels; and (d) developing the capacity of MoES to plan, programme and manage an investment portfolio that will effectively develop the education sector while ESSP emphasised education system that is relevant to Ugandan's national development and participation of all children in education.

Teachers for primary are recruited from among those who have completed 7 years of primary and four years lower secondary education plus two years of teacher training. They are trained in Primary Teachers Colleges (PTC) and are awarded a Grade III Certificate. However, the majority of students seeking admission to PTCs are mainly those who would have failed to join higher education of two years, which after leads to higher institutions of learning (Kagoda and Ezati, 2013). This means many not only lack a belief in their own potential but are unhappy to remain in the primary schools. According to Kagoda (2011) many teachers have a fairly negative image of their role plus an inadequate appreciation of the value of their work..

Although Grade III Certificate is the required educational qualification for teachers to teach in primary schools, it is not uncommon to find teachers with mixed qualification such as diploma and degree is primary schools. The situation is not made any better by the practice of recruiting head teachers from among those with diplomas and degrees even when the required qualification for headship is still Grade III Certificate. The tolerance of mixed qualification and the silent promotion of those with diploma and degree in primary schools have precipitated more upgrading. Consequently there are more teachers up grading. And luckily unlike before, today a teacher's opportunity to enhance his/her professional growth is unlimited given the large numbers of tertiary institutions in all regions of Uganda. Many universities are offering distance education with face to face teaching during holidays for teachers interested in upgrading their qualifications.

However it is not clear what pushes women to upgrade and whether they achieve their expectations after upgrading. What then happens to women given that the jobs they can be promoted to such as headship and other jobs in the district education office are very few? It is therefore clear that, what happens to female primary teachers after completion of their in-service studies have been inadequately addressed. The current study set out to address this gap by considering what women who upgrade their qualification do.

\subsection{Statement of the problem}

The required qualification to teach in a primary school is a Grade III Certificate. However since 1990, there has been massive up grading of qualification by primary teachers. It is becoming common for teachers in primary schools to upgrade to diploma, degree and even masters level. Although there is freedom to upgrade qualification, in the education sector, those qualifications neither guarantee salary increment nor changes in condition of service. The government insists that the required qualification for teaching in primary schools is certificate in teacher education (Grade 3 ). However, it is not clear how the teachers with high qualifications teaching primary schools cope with such a situation in their daily lives. 


\section{Purpose}

The main purpose of the study was to explore the status of women with high qualifications teaching in primary schools of Uganda.

\subsection{Objectives}

This study set out to investigate experiences of teachers in primary schools who upgrade qualification. Specifically it analyzed,

a) Women teachers' reasons for upgrading qualifications

b) The extent to which women teachers expectations of upgrading are met

\subsection{Methodology}

Researchers adopted a survey research design to provide basic that could provide a basis for further research in this area which has scanty data. The study adopted a combination of quantitative and qualitative research design in order to provide for a scope and depth of the issues under investigation. Qualitative data are useful when dealing with opinions, feelings and attitudes of participants. It is also useful when one needs to supplement, validate, explain, illuminate or interpret quantitative data generated from the same setting.

\subsection{Respondents}

This study was undertaken in three districts of eastern and northern Uganda. Only one district from each region was randomly selected to participate in the study from northern Uganda and two from eastern Uganda. From each district, with the assistance of the DEO, 10 schools with at least more than 3 women teachers who have upgraded qualification were sampled.

The study targeted those who have upgraded their qualification although those who have not up graded were also included. In each school two female teachers were selected. In addition, district education officials and members of the district service commission also participated in the study. This study was restricted to primary teachers who had attained Bachelors degree.

Table 1: Respondents for the study

\begin{tabular}{|l|c|c|c|}
\hline & Lira & Iganga & Kamuli \\
\hline Female Teachers (upgraded) & 20 & 20 & 20 \\
\hline female teachers (who have not upgraded) & 10 & 10 & 10 \\
\hline District Education Officers & 1 & 1 & 1 \\
\hline District Inspectors of Schools & 1 & 1 & 1 \\
\hline District Service Commission & 1 & 1 & 1 \\
\hline Total & 33 & 33 & 33 \\
\hline
\end{tabular}

\subsection{Data collection}

We worked from an interview protocol that allowed us to explore experiences of teachers after upgrading. We had slightly separate questionnaires that we used for women teachers who had upgraded and those who had not upgraded and district officials. Permission for interviews was gained from the district education offices, school administrators and the women teachers.

Data analysis involved reading through the data and identifying themes. Open coding that allows topics to emerge from the data, rather than beginning with preconceived codes were used. 
Data presented in this chapter were drawn represents voices of the women teachers and district education officials.

\section{Data presentation and discussion}

Majority of the women teachers who participated in this study had up graded in the last five years. This is shown in Table 2

Table 2: Duration since the last qualification

\begin{tabular}{|c|c|c|}
\hline & f & \% \\
\hline 5 years and below & 53 & 58.9 \\
\hline $6-10$ years & 31 & 34.4 \\
\hline More than 10 years & 7 & 7.8 \\
\hline
\end{tabular}

\subsection{Factors motivating women teachers in primary schools to undertake further studies}

Grade III certificate is the required qualification to teach in primary schools in Uganda. However more primary schools teachers are upgrading their qualifications up to degree level. The women were therefore asked factors that motivated them to pursue further studies; their responses are presented in Table 3.

Table 3: Factors motivating women to undertake further studies

\begin{tabular}{|l|}
\hline Reasons for up grading \\
\hline Higher salary \\
\hline To become a head teacher, DEO (promotion) \\
\hline Prestige \\
\hline To gain more knowledge and skills \\
\hline
\end{tabular}

As seen from Table 1, majority of the women teachers opted to upgrade qualification because of the urge to acquire more knowledge. The salary for a grade three teachers is currently equivalent to US $\$ 125$ which far below the living wage. The only way to move out of this poverty teachers imagine that by upgrading they might get a better paying job in non-government organization as teacher or any other better work outside the teaching profession. This is clearly illustrated in responses below;

I applied for a degree course because I wanted to leave classroom teaching and become child counselor with a Non Governmental Organization.

I wanted to move away from teaching to something better

I wanted to acquire more knowledge so that I can teach students in Primary Teachers' Colleges

\section{I wanted to get a good retirement package}

Working as a primary teacher means teaching all subjects, mathematics, English, social studies and science, as well as extra-curricular activities. A grade three teacher is trained as a general teacher (Kagoda and Ezati (2013), explaining this overworking of primary teachers and yet they pay is quite law. This situation makes the teachers imagine that by upgrading they will escape this condition. 
The second most popular reason for upgrading was promotion to either headship or District Education officer or Inspector of schools. This was reported by $32.2 \%$ of the women. Headship of primary schools is not only a prestigious position but also attracts more pay than classroom teaching. Although the required qualification for becoming a head teacher according to one of the District Inspectors of schools is 6 years teaching experience and a Grade III certificate, due to the high numbers of teachers who have upgraded, more diploma and degree holders are becoming head teachers. It is therefore not surprising that the women teachers enrolled for further studies in order to improve their chances of becoming head teachers do not get those positions.

Additionally, the importance attached to education as a necessity for getting jobs and promotion gained prominence in the late 1980s, when the current government took over power. After 1980, many employees realized that the only way to retain their jobs or get promotion is through up grading one qualification. It is partly this that led to massive quest for further education by civil servants including teachers. Thirdly the new government promoted women's rights and encouraged women to claim their rights and policies were formulated in favor of women, for example, the 1995 White Paper that recommended that female teachers should be given equal opportunity to become educational leaders.

The fourth most important reason was salary increment. In Uganda Public Service, salary payment is related to one's educational qualification. As one of the women explained, the only way to improve my pay is by upgrading'. Salary increment is however related to promotion. It is also not often true that upgrading would result into a salary increment. However, originally the teachers were not aware that the policy that a primary teacher is grade three therefore there was no way they could get better salaries after upgrading.

According to one of the inspectors of schools some women opt for upgrading in order to escape from marital problems. As she explained, 'some women take up course so as to rest from marital problems at home during the course in holidays This factor is an allegation since it was not mentioned directly by the women teachers, although many complained about marital problems while they were still undertaking the course. As one of them reported, my spouse one time told me not to return home'.

\subsection{Were the women teachers expectations achieved?}

Responses on whether they were able to achieve their expectations yielded mixed responses with majority confirming that they had achieved their wishes. All the women who wanted to gain more knowledge and skills achieved it. Although one of the women reported that she could not apply the knowledge in a primary school. This is because many of the students who opt to upgrade do not ensure that the courses they apply for are relevant to primary schools. There are many students who study secondary school teaching subjects like geography, history, fine art, biology, mathematic, etc and when they go back to primary schools, they realize it is irrelevant to the primary curriculum.

Of the 90 women teachers who participated in the study 18 were promoted to headship, 21 to deputy head teachers and the rest remained classroom teachers. Those who became head teachers had their salaries raised. However, those who remained classroom teachers, their salaries remained the same. There are cases where female teachers preferred to remain classroom teachers because of the fear to be posted to rural schools with poor access to urban areas, which lack of essential amenities; piped water, electricity, medical care, no staff houses etc.(Kagoda and Sperandio 2008). Another problem with rural schools especially for the unmarried female teachers is the fear of failing to get suitable well educated spouse.

Further, up grading qualification improve the women's status. As one of them explained, through upgrading I acquired more friends and I am able to rub shoulders with bosses in the district. For some female teachers, however, having high qualification is a threat to the officers who have lower or similar qualification. In addition the women who upgraded and left the teaching 
career, held various high caliber responsibilities such as in micro finance organizations, Board of governors, secretary of the various religious organizations. However as already mentioned some of the women did not achieve their expectations. These attribute their failure to get promotion to lack of vacancy, failure by the Ministry of Education and Sports to recognize their qualification, a 'push down' practice by those in authority. These are further discussed below.

\section{Lack of vacancy}

Promotion to the next level is only possible when there is a vacancy. However many of the women who upgrade proceed for the courses aiming to become head teachers even when those positions are filled. According to Uganda National Household Survey 2009/10, 76 percent of all primary schools in Uganda are managed by the Government. The majority $(80 \%)$ of primary schools in the rural areas are managed by Government while 51 percent of primary schools in the urban areas were managed by private entities. The owners of these private schools are also reluctant to employ women as head teachers as they are perceived as being weak and not authoritative enough to mange finances and the human resources. This means women teachers can only become head teachers in these government schools where there is a policy which clearly spells out that if the head is male, the female must be the deputy. To become a head or deputy head teacher one must go through an interview, which seems to be a threat to some female teachers. The interviews are conducted by the District Public Services and the panellists are dominated by men with at least one female panellist and the male individuals tend to intimidate female candidates. This partly explains why many female teachers do not become head teachers. This was confirmed by one of the inspectors from Iganga. As he said, 'even when one attains the qualification, there is no promotion, except when there is advertisement calling for application. In addition one cannot apply for headship if you are not a deputy head teacher'.

The inspector, however, adds on that many women teachers do not apply because of fear of responsibility; managing teachers, parents and pupils.

Further, many of the women teachers who upgrade could become senior education teachers, a position that was created in 2000 to provide promotional avenues for teachers. The findings showed that these were hard to achieve mainly due to corruption among the District Service Commission members. Corruption among the District Service Commission was often cited by the women teachers. As one of the women teachers from Iganga explained, men get promoted faster because they have tricks, they corrupt the district service commissioners. The DSC demands some money in order to be shortlisted and later interviewed. Similarly another woman also pointed out, 'This is why promotion to senior teacher is equally problematic. It is given by the DSC who interviews you but they also ask for money or sex. We women do not have money and are not ready to submit to this unethical behavior therefore we do not apply for such positions even if we see the advert".

Sexual harassment is not confined here but also in higher institutions of learning as noted by Kagoda (2011). Sex harassment is a reality for women in tertiary institutions especially those in lower ranks. Affected women are frequently intimidated to the extent that they often fail to assert themselves when aspiring for promotion.

\section{Failure by the Ministry of Education and Sports to recognize higher qualifications for primary schools teachers}

According to the Ministry of Education and Sports, Grade III Certificate remains the required qualification for one to teach in primary schools. The female teachers are frustrated;

Position has not changed. My salary has not changed. I regret having for a degree. In fact a friend advised me to remove the Graduate certificate and record myself as Grade I/I 
Teachers up grade without permission from the Ministry of Education and Sports and sometimes even without notifying their head teachers. This is possible because the programme is conveniently offered during school holidays. As a result after graduation many find it difficult to inform their head teachers and the MOES. One of the women reported, in this district nobody recognize our degree qualification, government at the district has a negative pronouncement "who sent you to upgrade?'

Still many Grade V and Grade 3 teachers remain head teachers while those with degree qualifications are ignored and remain classroom teachers. It is alleged that the head teachers are relatives of the district administrators. Explaining why they do not bother getting higher qualifications. Some people do not register as graduate teachers in the district after getting higher qualifications because of fear of mistreatment

\section{A 'push down' practice by those in authority}

There are many ways a teacher with high qualification is mistreated; At the school level a head teacher with lower qualification can make allegations such as;-

It worst when the head teacher is Grade III, they report you to the DEO, they claim you are disobedient, comes late to school, teaches poorly and all types of allegations. They do these so that you are sent to lower grade schools. This happens not only in schools headed by men but even female head teachers. The grading of schools is according to enrollment while head teachers in higher grades enjoying higher status and higher pay, those in lower grades schools get less. Bias against women remains strong in the three districts with people doubting their ability. A member of the School Management Committee wondered whether a woman can also lead. One participant reported that a board member said; "Women are lazy, problematic and lacking knowledge'. Society expects men to be natural leaders and challenging this stereotype is an uphill task. There is discrimination and marginalization of women in all forms of leadership. Moreover there are few role models and mentors of women aspiring to become leaders.

However, evidence is accumulating that women make excellent managers. They are accounted to be good organizers, planners, advisers, mentors, and calm, rational thinkers. Women excel in relationship building. In general they take fewer risks than men, which is now viewed, in the context of today's financial crises, as an asset (Obura 2011).

District Education Officers also fear people who upgrade; they think women with high qualifications will take their place. This explains why such women are posted in remote schools where they will not be noticed or heard of by stakeholders in education.

At schools you are also sidelined by the head teacher. My head teacher would remove all the responsibilities from me during the term but during holiday time, he would look for something to assign me and yet that is the time I report for classes.

Women who opt to take maternity leave are often viewed as failing to do their work and most young teachers in their reproduction age are rejected by head teachers accusing them of lowering the standard of the school through absenteeism.

You have a husband who leaves everything to you, a boss who may be worried that you will take his/her place, because you have higher grades than him, a DEO who fear you and posts you very far in remote schools.

The teachers added on;

Status of your husband influences the behavior of the administrators; unmarried teachers are mistreated at school, equated married women status to that of their husbands' status in society. Women married to men of high class in society are un-touchable and are likely to be promoted to headship if they wished. 
According to the inspectors (Iganga) "men feel they are undermined when their wives upgrade. Women shy away from teaching upper primary. They fear big boys and many teach lower classes. They feel inferior and fear too much work in upper primary'. These allegation justices the way female teachers are treated in this male dominated education sector. It is interesting to note that even female administrators mistreat fellow women teachers with high qualifications. Kagoda (2002) argues;

"In Uganda education officers are often men and most of the head teachers are also men. The female teacher has to work under this male dominated system. Some female teachers as opposed to their male counterparts do not even know how to write a curriculum vitae and in fact do not present one when appearing for an interview, reported one commissioner in Kamuli District. (pp212).

Young female teachers marry non professionals such as businessmen, who want a wife who returns home by $5.00 \mathrm{pm}$. So such women teachers would not aspire to become an educational leader. Once female teachers are appointed grade three teachers they do not want to lose their gratuity and pension. These women will endure mistreatment rather giving up their teaching job.

\section{Conclusion}

It is clear female teachers in Uganda have been inspired to upgrade their qualifications with the hope of gaining more knowledge and skills, others wanted to be promoted with the hope of increased pay, while others wanted to use it as a stepping stone to getter paying jobs.

A good number of female teachers have achieved their objectives, but a much bigger number is unknown to the education office, consequently, to the researchers and such teachers are frustrated, harassed by their head teachers and education officers. They are and mocked by teachers who have decided not to study and are at the same level in terms of salaries and other benefits.

\section{Recommendations}

The government of Uganda should set up a special commission to look into concerns of female primary teachers and ensure that fair treatment is meted out to them. It needs to sensitize female teachers about their rights and responsibilities, school management committees about their responsibilities in promoting teacher development, and district officials about inequalities that lead to poor performance by both teachers and pupils.

Female teachers need support, encouragement and time to plan their professional futures, more than their male counterparts do. Women teachers should be encouraged to create networks and form their own associations in order to overcome issues of self-esteem and sel-limiting practices. Stakeholders in education sector should be sensitized about gender issues and how they affect the development of the country.

\section{Acknowledgement}

The researchers are grateful to the female teachers, the education officers and other stakeholders in education in the three districts for their invaluable time and information.

\section{References}

BPA (1995). The United Nations 4th World Conference on Women, 15th September 1995: Beijing Declaration and Platform for Action, Available at www.un.org/womenwatch/daw/beijingplatform/ platl.htm. New York 
Kagoda A.M (2002) Determinants of Career and Professional Development of Female Teachers in four selected districts of Uganda, Geneva. International Federation Of University Women publications.

Kagoda A.M (2011) Assessing the Effectiveness of Affirmative Action on Women's Leadership in the Education Sector in Uganda. A paper presented in a UNESCO conference in Paris

6. Kagoda, A., \& Sperandio, J. (2008). Moving Beyond Historical and Cultural Understanding of Educational Leadersdhip. In H. Sobehart (Ed.), Women Leading Education Across the Continents: Sharing the Spirit, Fanning the Flame. New York, NY: Rowland and Littlefield Education.

Kagoda A. M \& Ezat A. B. (2013). Contribution of Primary Teacher Education Curriculum to quality Primary Education in Uganda. In Problems in Education in the 21st century. Volume 522013.

Katz-Gerro, T. \& Meir Yaish, M. (2003). Higher Education: Is More Better? Gender Differences in Labour Market Returns to Tertiary Education in Israel, Oxford Review of Education, Vol. 29, No. 4 pp. 571592 Available on http://www.jstor.org/stable/3595462. Accessed: 07/05/2013 06:48125

Kotecha, P. (1994). 'The position of women teachers' in Agenda: Empowering women for gender equity Volume 10, Issue 21, Special I ssue: Focus on Education pages 21-35

Nilan, P. (2003). Teachers' Work and Schooling in Bali International Review of Education / Internationale Zeitschrift fürErziehungswissenschaft / Revue Internationale de l'Education, Vol. 49, No. 6 (Nov., 2003), pp.563-584. Available at http://www.jstor.org/stable/3445398, Accessed on 07/05/2013 $06: 40$

Obura, A. P., Wamahiu, S. P., Kariuki, W., Bunyi, G, W., Chege, F., Njoka, E., Ruto, S., Ministry of Eduction, Kenya (2011). Gender Equality in Education: Looking beyond parity: Global Literature Review on Gender Equality in Educational Planning and Managment. An IIEP evidence-based Policy Forum 3-4 October 2011, Paris

Sperandio.J . and Kagoda. A.M. (2010) Women Teachers' Aspirations to School Leadership in Uganda. In International J ournal of Educational Management. Volume 24 (1)

Vravec J., \& Bacik R. (2012) Discrimination of women in the Labour market of SR and Models of discrimination in Polish J ournal of Management pages 280 - 293

Republic of Uganda (1992) The Government White Paper on the Education Policy Review Commission Report. Entebbe Government Printing Press 